\title{
腹腔鏡下手術時に偶然発見された高分化型乳頭状中皮腫の対応
}

総合東京病院 婦人科 ${ }^{1}$ 、新百合厅丘総合病院 産婦人科 ${ }^{2)}$

齋藤 裕 ${ }^{1}$ 、佐々木恵子 ${ }^{2}$ 、関川佳奈 ${ }^{2}$ 、佐藤美和 ${ }^{2}$ 、

原周一郎 ${ }^{2)}$ 、永井 崇 ${ }^{1)}$ 、田島博人 ${ }^{2)}$ 、浅田弘法 ${ }^{2)}$

\section{Laparoscopic procedure for well-differentiated papillary mesothelioma incidentally found during laparoscopic surgery: A case report}

\author{
Yutaka Saito $^{1)}$, Keiko Sasaki ${ }^{2)}$, Kana Sekigawa ${ }^{2)}$, Miwa Sato ${ }^{2)}$, Shuichiro Hara ${ }^{2)}$, \\ Takashi Nagai ${ }^{1)}$, Hiroto Tajima ${ }^{2)}$, Hironori Asada ${ }^{2)}$ \\ Department of Gynecology, Tokyo General Hospital ${ }^{1)}$ \\ Department of Obstetrics and Gynecology, Shin-Yurigaoka General Hospital ${ }^{2)}$
}

\begin{abstract}
Mesothelioma is a rare malignant tumor that occurs from the pleural and the peritoneal mesothelial cells. Welldifferentiated papillary mesothelioma (WDPM) is a subtype of low-grade mesothelioma, the majority of which are asymptomatic and often discovered and diagnosed by chance during surgery. This time, we incidentally found spontaneous peritoneal uplift lesions and resected them using laparoscopic procedure when we performed a laparoscopic hysterectomy for the uterine fibroids. The pathological examination result was WDPM. We consider the significance of responding to incidental peritoneal lesions based on a rapid tissue examination during surgery and the technical key points of laparoscopic resection of peritoneal lesions.
\end{abstract}

Key words: well differentiated papillary mesothelioma; laparoscopic surgery; peritoneal lesions

\section{【緒言】}

中皮腫は胸膜や腹膜の中皮細胞から発生する稀 な悪性腫瘍であり、悪性度も様々である。また石 綿暴露との関連が知られている ${ }^{1)}$ 。その中で高分 化型乳頭状中皮腫（well-differentiated papillary mesothelioma：以下WDPM）は低悪性度中皮腫 の一亜型で腹膜発症が多い ${ }^{2-4)}$ 。生殖可能時期の女 性に多く、石綿暴露との関連は低( ${ }^{2-4)}$ 。低悪性度 ゆえにほとんどが無症状で、外科手術の際に偶然 発見され診断されることが多い5.6)。今回我々は子 宮筋腫に対し腹腔鏡下子宮全摘術を行った際、偶 然孤発性の腹膜隆起病変を認め腹腔鏡下に切除 し、病理組織診でWDPMと診断した症例を経験 したので、腹腔鏡下手術における腹膜病変切除の 観点から考察を交えて報告する。な挔、対象とな る個人からは文書で同意を得た。
【症例】

患者：47歳 0 妊

主訴：検診で子宮筋腫を指摘され当科紹介

既往歴：特記事項無し、石綿暴露歴無し

家族歴：特記事項無し

月経歴：30日周期、順

現病歴：45歳時の婦人科検診で子宮筋腫を指摘さ れ当科を受診した。内診上子宮は手拳大で可動性 良好であった。経胵超音波検査ではダグラス窩に 占拠病変は無く、腹水も認めなかった。骨盤部 MRI検查では子宮前壁に長径 $7 \mathrm{~cm}$ の漿膜下 - 筋 層内筋腫を認めたが、悪性を示唆する所見や他の 粗大病変は認めなかった。患者に自覚症状は無く、 経過観察とした。47歳時の定期診察で、本人から 腹部圧迫感の訴えがあり、再度骨盤部MRI検查を 行った。その結果、長径 $12 \mathrm{~cm}$ に子宮筋腫が増大 
していた（図 1 )。術前の子宮胵部・内膜細胞診 に異常は認めなかった。術前に腫瘍マーカー検査 は行わなかった。患者の希望も踏まえて、腹胅鏡 下に根治手術を行った。

手術所見：臍部からオープン法で $12 \mathrm{~mm}$ トロッ カーを挿入および気腹を行い、ダイヤモンド法で 手術を開始した。子宮は前壁漿膜下－筋層内筋腫 のため超手拳大に腫大していた。両側付属器は肉 眼上正常であった。腹水はごく少量認めた。腹腔 内に癒着所見は無かった。手術開始時の観察範囲 内には、播種巣や隆起病変の悪性腫瘍を示唆する 所見は認めなかった。

腹腔鏡下に子宮全摘術と両側卵管切除術を行っ た。途中子宮頸部の子宮血管処理を行っている際、 後腹膜に径 $5 \mathrm{~mm}$ ほどの乳頭状に隆起する腫瘍性 病変を視認した。両側とも隆起部は複数あったが、 直径 $2 \mathrm{~cm}$ 程度の範囲に各々限局していた（図 2 )。 病変の性状から悪性腫瘍を疑ったが、当院では術 中迅速組織診を行えなかった。病変部切除を行い、 永久病理標本で治療方針を決めることとした。先 に子宮を摘出し腟式に回収した。その後、腫瘍ご と後腹膜を切除するために岡林直腸側腔を開放 し、尿管を外側に授動した。腫瘍の腹膜浸潤は軽 度であり開放は容易であった。後腹膜切除をする 内側のラインは仙骨子宮勒帯とし、腫瘍の切除マ ージンは結果として $1 \mathrm{~cm}$ とった。腟断端の後 腹膜は開放とした（図 3 )。その後、他に同様の

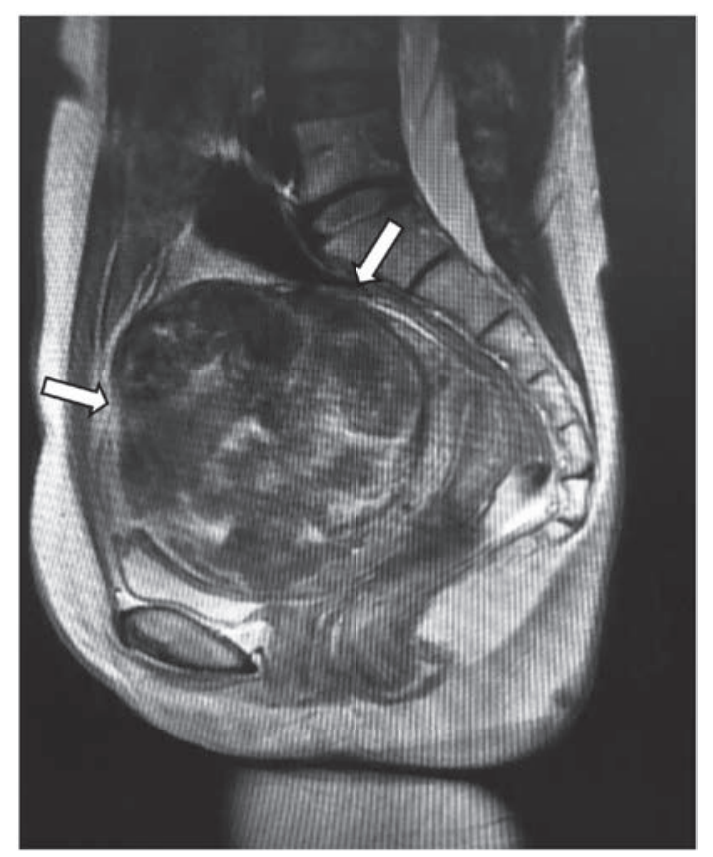

図1 骨盤部MRI検査 (T2強調画像、矢状断)

T2強調画像で内部高信号と低信号が不均一に混在す る、辺縁平滑な腫瘤を認め (矢印)、子宮筋腫と診断し た。両側付属器は正常、ダグラス窩に異常所見を認めず。
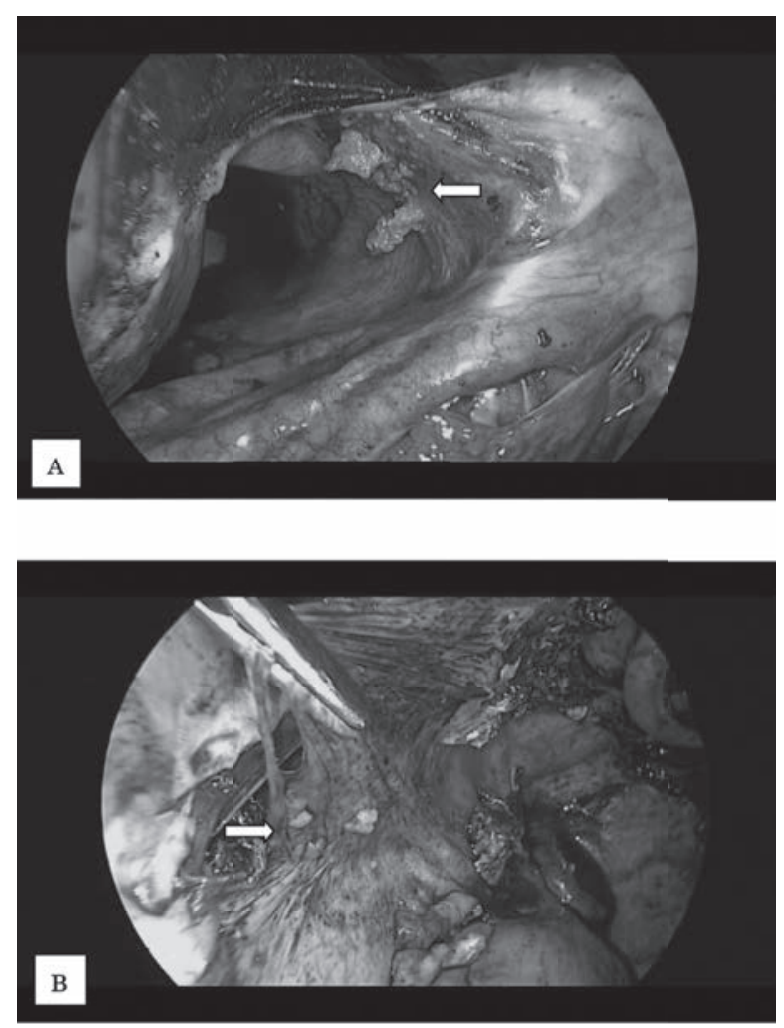

図2 腹腔鏡手術所見 ( $A$ 右側、B 左側) 骨盤腔左右後面に乳頭状隆起病変を認める (矢印)

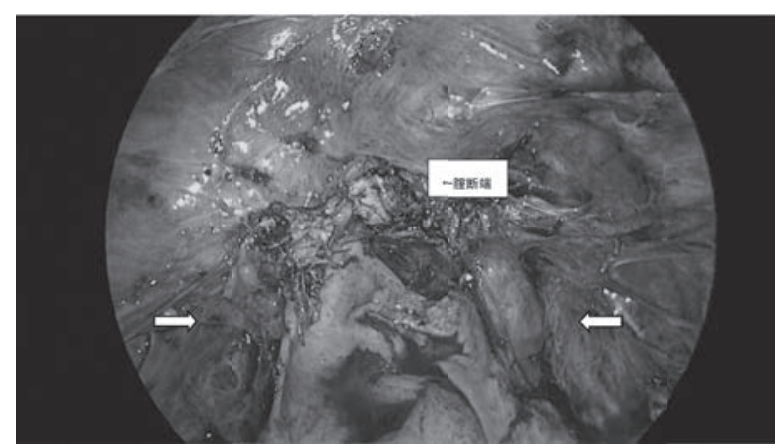

図 3 腹膜隆起病変を摘出後 両側腹膜の剥離切除後 (左右矢印)

病変が無いか、骨盤内を再検索した。腸間膜や大 網は腸把持鉗子を用いて手繰り寄せながら観察し た。他に明らかな病変は認めなかった。この時ダ グラス窩に貯留していた腹水を採取し細胞診に提 出した。摘出した検体は腹腔内で回収バッグに収 容し、腟断端を閉鎖する前に腟より回収した。手 術時間は 3 時間 34 分、術中出血量は $80 \mathrm{~g}$ 、子宮重 量は853 gであった。

病理学的診断 : 腹膜病変の病理像は、腹膜表面に 連続して、中皮細胞が線維血管性間質を軸とする 複雑な分枝乳頭状の増殖を示していた（図 4 )。 中皮細胞は比較的均一な類円形核を有し、乳頭構 築の表層を概ね単層に被覆していた。所々では、 

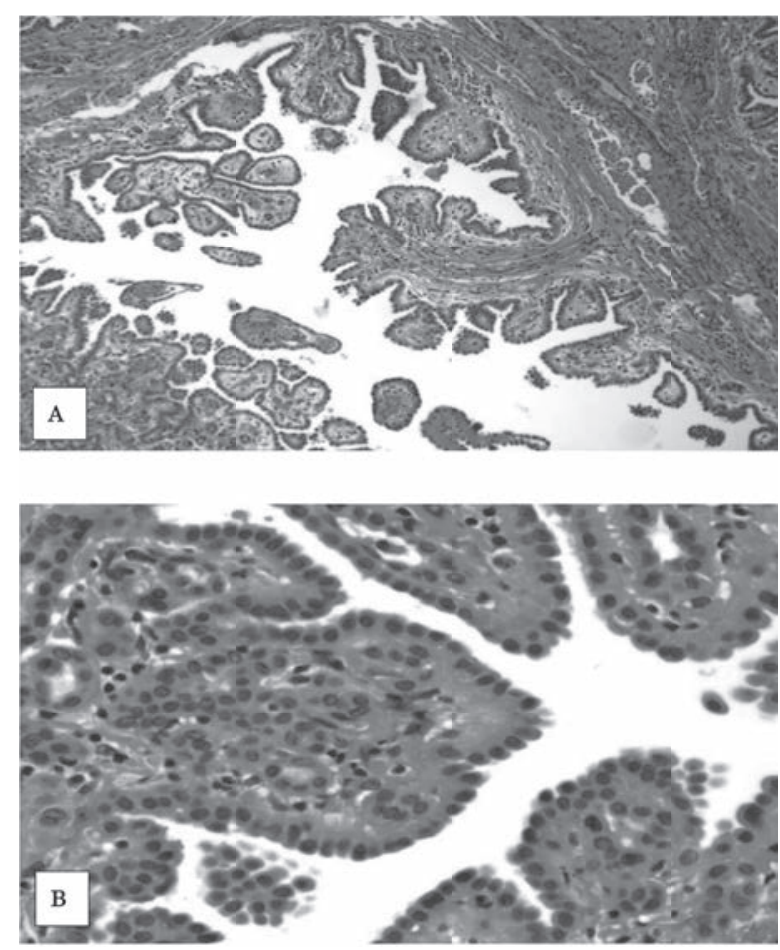

図4 病理組織学所見 (HE染色A ; $\times 100 、 B ; \times 400)$ 腹膜表面に連続して中皮細胞が線維血管性間質を軸として分 枝乳頭状に增殖している。中皮細胞は比較的均一な類円形核 を有し、乳頭構築の表層を概ね単層に被覆、核分裂像は殆ど 見られず。

中皮細胞が間質軸を埋めるように小管状・小胞巣 状・索状に増生している個所も認め、限局的な浸 潤性増殖が示唆された。但し核分裂像は認めなか った。一部に間質の出血、泡沫状組織球集簇を認 めた。免疫染色Ki-67は $5 \%$ に陽性を示した。以 上より、高分化型乳頭状中皮腫と診断した。腹水 細胞診に異型細胞は認めなかった。子宮は平滑筋 腫であり、両側卵管に異常所見は認めなかった。 術後経過：術後は経過良好で術後 4 日目に退院し た。退院 3 週間後にPET-CT検査を行ったが、転 移所見は認めなかった。相談のうえ化学療法等の 追加治療は行わず、当科で経過観察の方針とした。 以後定期フォローを行っているが、術後 1 年半経 過した時点で特に異常所見は認めていない。

\section{【考察】}

本症例のような腹膜病変に偶然遭遇した場合、 術式判断には術中迅速組織診が重要であり、腹膜 ごと合併切除する必要がある。WDPMは多くが 無症候性の低悪性度病変であるが、高悪性度病変 に転化した報告がある ${ }^{7.8)}$ 。WDPMには限局型と びまん型があり 5.6 、外科切除が第一だが、びまん 型で病変が広範囲に及ぶ場合、完全切除は困難で ある。そのため術後に化学療法が追加されること
がある。明確な選択肢はないがプラチナ製剤やぺ メトレキセドの使用実績がある1)。最近では中皮 腫同様に腹腔内温熱化学療法の報告がある ${ }^{9)}$ 。

術中偶発的に悪性腫瘍を疑う病変を認めた場 合、術中迅速組織診により術式を決定することが 重要である。その結果が高悪性度病変であった場 合、原発巣や腹腔内播種の検索と、腫瘍減量を含 めた術式に関して、病理学的診断に基づいた適切 な対応を行う。腹腔内検索では、術前のCTや MRI検查では微小病変の評価は困難である。鏡視 下手術では拡大視が可能であり詳細な腹腔内観察 が行える一方、触診には限界があり必要に応じて 開腹して検索する。な㧍術中迅速組織診で本症例 のようにWDPMであった場合、びまん型WDPM の可能性を考慮しつつ、腹腔鏡下に播種巣の検索 を行う。術式では高悪性度病変であれば、必要に 応じて開腹手術へ移行する。腹膜病変は肉眼的残 存が無い状態を目指し、腹膜切除 (peritonectomy) を行う ${ }^{10-12)}$ 。術中迅速組織診でWDPMと診断され ても、肉眼的残存が無いよう腹膜病変の切除は必 須である。そのため腹腔鏡下であっても次に示す 要点に則った方法で腹膜病変を切除する。

腹腔鏡下手術における腹膜病変切除に関して要 点を三点提示する。第一は尿管授動である ${ }^{10,11}$ 。 岡林直腸側腔を開放してmesoureterごと尿管・ 下腹神経を後腹膜から剥離・側方に授動して、後 腹膜を切除する。尿管剥離が骨盤入口部まで達す ると、より広範囲な腹膜切除が可能である。第二 は剥離操作の際、鉗子で腫瘍の直接把持を避ける。 特に悪性腫瘍を疑う場合、腫瘍周囲の正常腹膜か ら展開し、充分な余剩を取って剥離し、直接把持 による腫瘍の飛散を防止する。検体回収も収容バ ッグ搬出時にポート刺入部が内容液で污染されな いよう、port site metastasisに注意する ${ }^{13)}$ 。第三 は鉗子の侵入角度には限界があり、腹膜切除ライ ンに合うようにトロッカー及びデバイスの角度を 調節する。直腸側方なら鉗子の可動域に問題は生 じないが、直腸前面や腹壁前方は動作範囲が制限 される。そのためダイヤモンド法で不十分であれ ばトロッカーの追加や、あるいはENSEAL ${ }^{\circledR} \mathrm{G} 2$ Articulatingのような先端が屈曲するパワーデバ イスの使用を考慮する。ただし広範囲に及ぶ腹膜 病変の場合、根治的切除は容易では無く、腹腔鏡 下手術での手技上の限界もあり、腹腔鏡下で続行 するか開腹術へ移行するか見極めが重要である。

我々が調べた限り本邦の婦人科領域では、腹腔 鏡下の腹膜切除に焦点を当てた報告は会議録を除 
くと本報告が初めてである。欧州では、卵巣癌の 術前化学療法後の腹腔鏡下での interval debulking surgeryで、30例中11例に局所的腹膜 切除が行われ、29例がcomplete surgeryであった 14)。また横隔膜の子宮内膜症病変に対し、腹腔鏡 下での横隔膜下腹膜の一括切除の報告がある ${ }^{15)} 。$ 今後は本邦でも腹腔鏡下での腹膜合併切除は様々 な症例で汎用され得ると考える。

今回術中迅速組織診を行わなかった点は反省す べきである。結果的に二期的な手術をせず経過観 察となったが、リンパ節や横隔膜の触診まで行う べきだったか、あるいは腹腔鏡下での腹膜病変切 除に留めて妥当だったのか、その判断のため術中 迅速組織診は必要であった。今回は腹腔鏡下で視 認範囲内の腹膜病変は切除出来たが、腹腔内検索 に関しては充分では無かった。術中迅速組織診の 対応に施設で差はあるが、今回の「腹腔鏡下に腹 膜病変のみ切除した」という術式の妥当性に術中 の病理学的裏付けが無かった点は反省すべきとこ ろである。

\section{【結 語】}

今回我々は腹腔鏡下手術の際に偶然遭遇した WDPMの症例を経験した。偶発的な腹膜病変に 対して、術野の入念な観察と術中迅速組織診によ る対応が重要であり、腹腔鏡下での腹膜合併切除 に習熟する必要がある。

本論文の要旨は第58回日本産科婦人科内視鏡学 会学術講演会において発表した。

すべての著者は開示すべき利益相反は無い。

\section{【文献】}

1 ) 国立がん研究センターがん情報サービス 中 皮腫 : http://ganjoho.jp/med_info/guideline/ evidence/list/edb_mesothelioma.html（最終 アクセス日2019年7月1日）

2 ) Sun M, et al. : Well-differentiated papillary mesothelioma: A 17-year single institution experience with a series of 75 cases. Ann Diagn Pathol 2018 ; 38 : 43-50

3 ) Galateau-Salle F, et al. : Well-differentiated papillary mesothelioma of the pleura : a series of 24 cases. Am J Surg Pathol 2004 ; 28(4) : 534-540

4 ) Anais Malpica, et al. : Well-differentiated papillary mesothelioma of the female peritoneum : A clinicopathologic study of 26 cases. Am J Surg pathol $2012 ; 36(1)$ : 117-127

5 ) 長谷川明俊、他 : 腹腔鏡下子宮筋腫核出術時 に偶然発見された高分化型乳頭状中皮腫の一 例、日産婦内視鏡学会誌 $2010 ; 26: 575-579$

6 ) 隈本力、他 : 腹腔鏡下に完全切除された高分 化型乳頭状中皮腫の1例、日臨外会誌 2014 ; 75(4) : 1071-1075

7 ) Torii I, et al. : Well-differentiated papillary mesothelioma with invasion to the chest wall. Lung Cancer 2010 ; 67(2) : 244-247

8 ) Costanzo L, et al. : Malignant transformation of well-differentiated papillary mesothelioma 13 years after the diagnosis : a case report. Clin Respir J $2014 ; 8(1)$ : 124-129

9) Deraco M, et al. : Well differentiated papillary peritoneal mesothelioma treated by cytoreduction and hyperthermic intraperitoneal chemotherapy - the experience of the PSOGI registry. Eur J Surg Oncol 2018 ; (18) : 31468-9

10) Sugarbaker PH : Peritonectomy Procedures. Ann Surg Oncol 1995 ; 221(1) : 29-42

11) Sugarbaker PH : Complete parietal and visceral peritonectomy of the pelvis for advanced primary and recurrent ovarian cancer. Cancer Treat Res 1996 ; 81 : 75-87

12) 卵巣がん治療ガイドライン 2015 、日本婦人科 腫瘍学会編 : 154-155

13) Nunez MF, et al. : Port-site metastasis is an independent prognostic factor in patients with peritoneal carcinomatosis. Ann Surg Oncol $2015 ; 22: 1267-1273$

14) Alletti SG, et al. : Minimally invasive debulking surgery in ovarian neoplasm (MISSION trial NCT02324595) : a feasibility study. Am J Obstet Gynecol 2016 ; 214(4) : 503.e1-503.e6

15) Chiantera V, et al. : Laparoscopic en bloc right diaphragmatic peritonectomy for diaphragmatic endometriosis according to the Sugerbaker Technique. J Minim Invasive Gynecol 2016 ; 23(2) : 198-205

投稿日: 2019年 7 月 26 日 採択日: 2019年12月18日 